Natural Hazards and Earth System Sciences (2003) 3: 583-592

(C) European Geosciences Union 2003

Natural Hazards and Earth System Sciences

\title{
Stationarity analysis of historical flood series in France and Spain (14th-20th centuries)
}

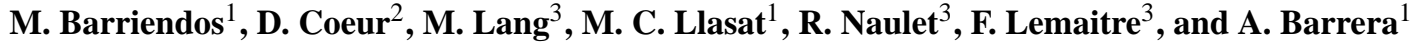 \\ ${ }^{1}$ Department of Astronomy and Meteorology, University of Barcelona, Spain \\ ${ }^{2}$ ActhYs-diffusion, Grenoble, France \\ ${ }^{3}$ CEMAGREF, Unité de Recherche Hydrologie-Hydraulique, Lyon, France
}

Received: 12 February 2003 - Revised: 18 September 2003 - Accepted: 4 November 2003

\begin{abstract}
Interdisciplinary frameworks for studying natural hazards and their temporal trends have an important potential in data generation for risk assessment, land use planning, and therefore the sustainable management of resources. This paper focuses on the adjustments required because of the wide variety of scientific fields involved in the reconstruction and characterisation of flood events for the past 1000 years. The aim of this paper is to describe various methodological aspects of the study of flood events in their historical dimension, including the critical evaluation of old documentary and instrumental sources, flood-event classification and hydraulic modelling, and homogeneity and quality control tests. Standardized criteria for flood classification have been defined and applied to the Isère and Drac floods in France, from 1600 to 1950 , and to the Ter, the Llobregat and the Segre floods, in Spain, from 1300 to 1980.

The analysis on the Drac and Isère data series from 1600 to the present day showed that extraordinary and catastrophic floods were not distributed uniformly in time. However, the largest floods (general catastrophic floods) were homogeneously distributed in time within the period 1600-1900. No major flood occurred during the 20th century in these rivers. From 1300 to the present day, no homogeneous behaviour was observed for extraordinary floods in the Spanish rivers. The largest floods were uniformly distributed in time within the period 1300-1900, for the Segre and Ter rivers.
\end{abstract}

\section{Introduction}

The last report of the IPCC (IPCC, 2001) shows that an increase in climate variability and some extreme events could be projected as a consequence of the increasing atmospheric concentrations of greenhouse gases and aerosols. Concerning floods, new scenarios of strong climatic variability and global change may justify the detailed reconstruction of flood events from proxy-data. The final objective would be to im-

Correspondence to: M. Barriendos (mbarriendos@ub.edu) prove knowledge about the various features of these events (meteorological conditions, temporal and spatial distribution, and magnitude of singular events and damage produced) in different climatic scenarios. The temporal changes in human responses and impacts in the face of floods could also be elucidated on the basis of this kind of information.

The modern instrumental period cannot cover natural phenomena characterised by a very low frequency. For this reason, the reconstruction of flood event chronologies and their atmospheric patterns when produced by extensive or heavy rainfall can be estimated from proxy-data contained in documentary sources. This information is available for the past millennium in particular locations, and for the last 500 years in a large number of locations throughout Europe (Barriendos et al., 1998; Barriendos and Martin-Vide, 1998; Brázdil et al., 1999; Coeur and Lang, 2002; Llasat and Barriendos, 2001; Glaser and Stangl, 2003). But an objective analysis calls for the definition of methods and statistical procedures to produce calibrated series and reconstruction of data in quantitative conventional format. The scientific community is now taking the first steps in this interdisciplinary line of research.

This paper will deal with different methodological aspects concerning the study of flood events in their historical dimension: critical evaluation of old documentary and instrumental sources (Sect. 2), flood-event classification and hydraulic modelling (Sect. 3), homogeneity and quality control tests (Sect. 4).

The following ideas have been produced in the framework of the SPHERE project, a European Commission research project, whose aim is to improve flood risk assessment using systematic and non-systematic information, such as historical and palaeoflood data (Benito et al., in press). 


\section{Documentary and old instrumental sources in the study of large flood events}

Several theoretical and practical problems are related to flood reconstitution from documentary sources (Coeur et al., 1998). One major pitfall of this type of investigation is the fact that the testimonies of the history of natural events tend to have an anthropocentric bias. How can we tell the difference between the interpretation of a hydrological event by a witness in a particular cultural context and its true reality and characteristics? First, we must assume that all archive testimonies are more or less biased. Each one is an interpretation in a cultural and socio-economical context. Although the development of technical and scientific knowledge, with instrumental observations since the end of the 17th century, resulted in an information explosion, scientifically-based testimonies are still fewer in number than those produced by economic, politic, social and cultural activities.

\subsection{Documentary source availability}

The quantitative importance and variety of documents is the first problem to resolve. When it comes from environmental information, the chance of finding a new item about a phenomenon could extend to any type of document from a country's documentary heritage. In fact, all kinds of old documents can contain some description of meteorological or hydrological aspects concerning a flood event or damage occurring directly or deferred in time. As it is impossible to investigate all the archives, priority analyses are necessary.

Different levels of source collections must be investigated in time in relation to the need for detail. In this perspective the major collections potentially containing climatic information and its effects, such as floods or droughts, are: Local Government collections (e.g. Municipal council archives); State government collections (administrative, fiscal, military, public works, legal and diplomatic archives); Religious collections (episcopal, diocesan, parish or monastic archives); Private collections (noble families, memoirs of farmers and the professional classes, and corporate archives); Notaries' archives (property conveyancing and sales, donations, assignments and rights).

A general inventory is used to identify the main groups of documents. In France, public archives have been classified for administrative purposes into inventories under various subject headings, as for example police and general administration series ( $\mathrm{C}$ or $\mathrm{N}$ series), public works affairs ( $\mathrm{S}$ or W series after 1800). Similar organising structures exist in other national documentary heritages, but each is characterised by its historical context and dynamics. For instance, Spanish administrative sources from State organizations provide relatively little information on the everyday aspects of human communities from the Middle Ages to the mid-19th century compared to local and ecclesiastical authorities. These inventories make the first step of research easier. At this stage, sampling of documents through this inventory provides an assessment of the quality of the larger and unknown docu- ment groups. A General State of Sources (GSS) is then completed during the investigation. This provides the research work plan and finally indicates the documentary course to be followed (Naulet et al., 2001).

\subsection{Selection criteria on documentary series}

Not all documentary sources can yield useful information for reconstruction and characterisation of flood events or, in general terms, environmental conditions. But selection criteria may be applied with the objective of obtaining the best data series with the best possible quality. In this perspective, it is important to cross-validate information using several testimonies on the same event and using several geographic scales of analysis in order to assess its spatial extent. Basic questions on the nature of the document, the author and his intentions must always be asked, by examining the original testimony (source analysis).

The following list of criteria is derived from previous experience in different case studies (Le Roy Ladurie, 1967; Alexandre, 1987; Pfister, 1988; Barriendos and Martin-Vide, 1998; Brázdil et al., 1999): a) Accessibility of the documents: The documentary series must be available to the public under optimum working conditions to allow orderly consultation within a reasonable time. b) Continuity of the records: The documentary series must have temporally continuous records to ensure that there was no flood that eluded the recording system. Discontinuity problems can arise at the time the documents were produced or due to subsequent accidents or destruction. c) Reliability of the documents: The documents must come from a highly reliable source, precluding in so far as possible errors of interpretation, translation or transcription. In order to ensure the reliability of a document, two factors should be considered: firstly, the scribe or recounter of the record must be a contemporary witness of the facts recounted; secondly, the documents must be originals (copies or transcriptions must be identified as such and treated with the utmost prudence). d) Objectivity of the information: The person or group creating a documentary record must be objective and impartial.

Obviously, an initial selection would have to examine those collections with information about the day-to-day lives of human communities and all the problems affecting them. Accumulated experience to date suggests that better results are to be expected from local authority collections and local ecclesiastical authorities (parishes and particularly cathedral sections or convent/monastery communities) than from State government and private documentary collections.

The final quality of a testimony will be assessed through a long critical process, taking into account the intrinsic quality of the document (type, author, date, circumstances of writing, etc.). As complete reproduction is advisable when data and information are particularly important (e.g. maps, general reports), it is essential to use computer tools and database systems when dealing with numerous historical documents. Such tools are particularly useful for the instrumental data 
series available in large towns since the second half of the 18 th century (rainfall, temperatures, hydrometric data).

Three technical aspects must also be mastered throughout the documentary investigation: palaeography, to ensure the correct interpretation of the text and old instrumental data; chronology, to ensure continuity in a standard up-to-date calendar and metrology for the same reason because of changes in measurement units.

Overall, a good historical documentary approach should be concluded with three chronological accounts of: a) those local administrations and municipalities who were in charge of land planning or produced technical data (topography, hydrology); b) methodologies and measuring instruments used to analyse natural phenomena (science and technology); c) catchment events, such as floods but also major land-use changes in the basin and along the river (e.g. public works). These panels constitute the background of the critical investigation plan (Coeur and Lang, 2002).

\subsection{Data collected}

The information usually collected contains the following items: data on the meteorological phenomenon that was the main cause of the overflowing of banks, the exact dates and duration of the flood event and detailed description of the direct and deferred impact on infrastructure and on the population. Quantitative references on the behaviour of the rising waters is sometimes found, such as the levels reached or the zones flooded. The flood level can be measured directly, from the height of the water at a precise location, or indirectly, from references to the presence of water at some particular architectural feature. Public works files are particularly valuable for this data collection.

Useful information for the reconstruction of public works close to river beds can be found in local authority collections themselves such as public works dossiers, maps or plans, and specific series on hydraulic infrastructures, all of which can help in the reconstruction of the river bed with quantitative information. But also state archives focused on public works or river authorities contain good data series and cartographic material to help in this characterisation. Documentary data gathering from these series can yield qualitative information but also information on the dimensions of various infrastructures close to the river channel (dikes, bridges, dams, irrigation channels, mills) and maps on various scales of the bed of the river and providing an understanding of its dynamics over time. The documentary and old instrumental sources analysed can thus be used to build flood event classifications.

\section{Flood event classification from French and Spanish experience}

We know that floods, like other recurrent natural hazards, cannot be defined only in space but can also be defined with time. A river flooding identity is, first, a family of events. For recent decades, events are known directly by instrumen-
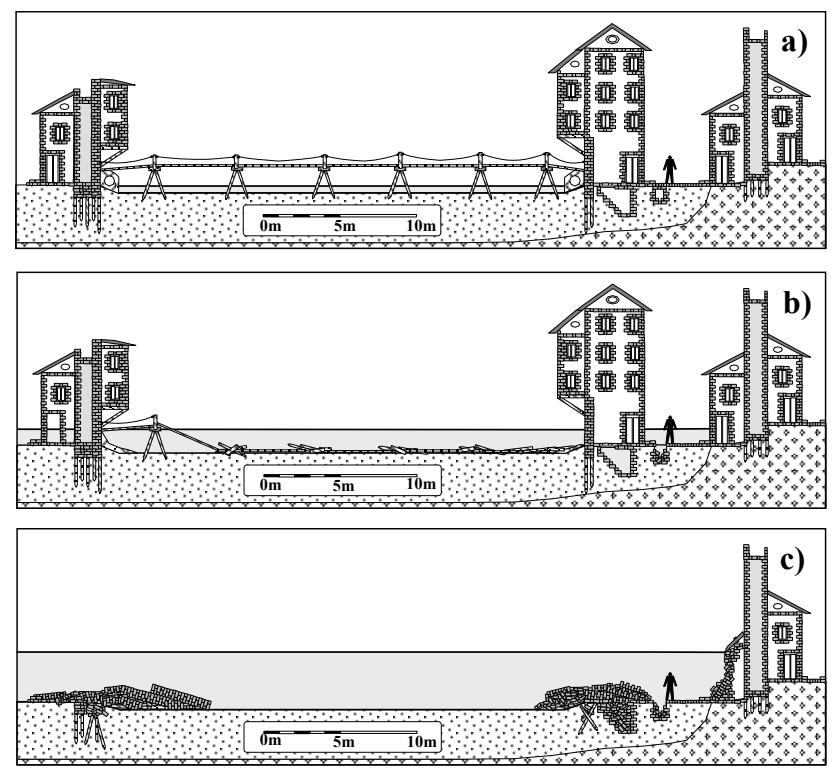

Fig. 1a. Graphic example of flood events from documentary sources classification. (a) Situation normal or ordinary rise. (b) Situation of extraordinary flooding. (c) Situation of catastrophic flooding (The section reproduces the conditions of the River Onyar as its passes through the city of Girona).

tal observations (data series). But how can we take into account the data of previous centuries? The flood event classification is a way for identifying extreme floods in a long series of events and for eventually specifying, their temporal variability. We propose a double approach of first comparing flood levels and damage criteria and secondly hydraulic modelling.

\subsection{Historical data series based on flood levels and damage}

Experience in historical data collection defines the minimum consistently available information that is obtainable from documentary sources about flood events. Obviously, for the pre-instrumental period, the information available for generating a tool for flood classification focuses on scattered records of water levels and impacts. Without instrumental data and hydrological analysis, a scale of event magnitude can be proposed using the flood effects on the river bed and surrounding areas. In this case, damage to human infrastructure provides some information but it is not the only information source. Geomorphological changes also highlight the nature of the phenomenon (sediment transport, river bed changes, etc.). This is the case in the following classification, which comprises three levels, based upon hydrological criteria and the impact level caused directly by the flooding (Figs. 1a and 1b). This classification combines the criteria developed by the authors after the systematic analysis of Spanish and French historical floods: 1) Ordinary rise or small flood: Scarcely differs from the normal situation of the river. A rise does not involve the river channel overflowing. No serious damage or destruction is caused to 


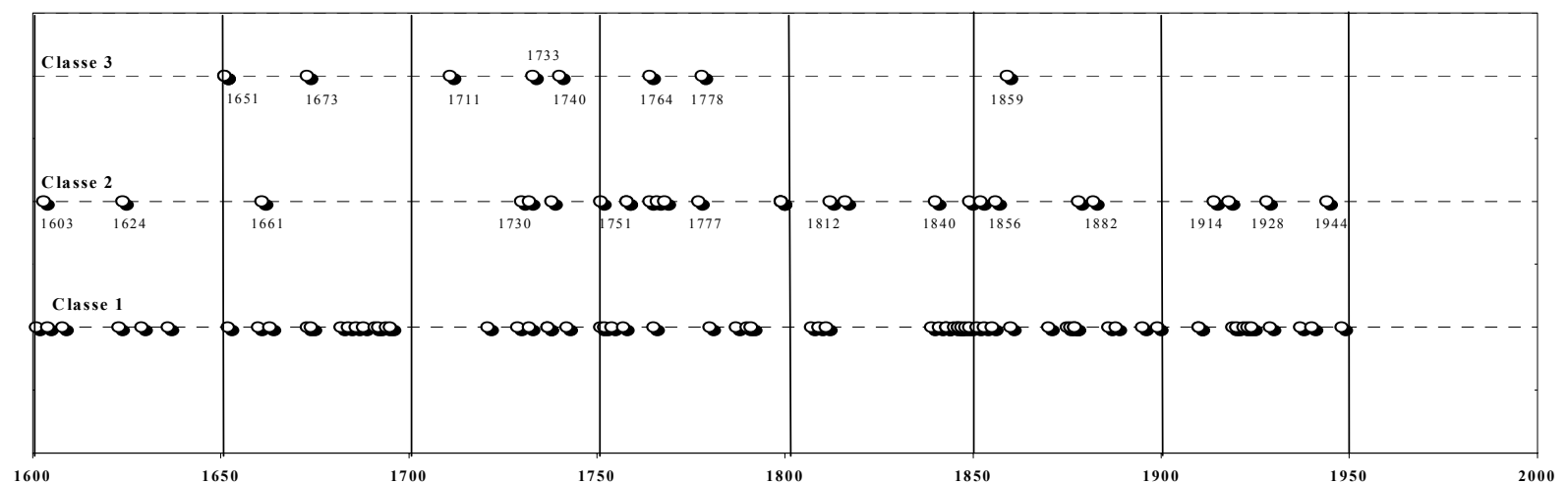

Fig. 1b. Ranking of flood events on Isère river at Grenoble (1600-1950).

the population, but minor damage to hydraulic installations such as mills or irrigation channels cannot be ruled out. The river is locally or totally affected but banks, dikes, bridges or other works are not much damaged. Flooding of some area is possible but remains restricted. Overflows depend on the degree of river bed obstruction and on the state of dikes. 2) Extraordinary flooding or intermediate flood: The flow of the river is sufficient to overflow the usual channel. Water is present in the streets or sectors under study, although the level reached in them can be variable. Damage can be only slight, although usually damage to hydraulic installations adjacent to or in the channel, such as mills, irrigation channels, dams or footbridges can be severe, with partial destruction. This class includes large events, which affect the whole or only a part of the river course. Banks are overflowed in several places. Infrastructure is destroyed along several hundred meters (roads, dikes). Bridge piers and abutments are eroded and damaged. The flood perimeter is very large and there is heavy sediment transport. 3) Catastrophic flooding or large flood: The flow of the river is sufficient to make it overflow its usual channel. The levels reached can be the same as or exceed those of an extraordinary flooding episode. The difference lies in the strength or capacity of the overflowed channel to cause severe damage or complete destruction of infrastructures close to the river (bridges, dams, dikes, walls, mills, houses, drainage systems, irrigation channels). Furthermore, the overflowing can affect zones away from the channels and also with destructive effects. Dwellings may collapse, sections of roadways may be destroyed, crops may be lost and shrub and tree species may even be uprooted and dragged away. There are large morphological changes to the river, with river bed transformation and meander captures.

This classification has been applied to the Isère and Drac floods in France, from 1600 to 1950 , with a critical period from 1650 to 1780 (see Fig. 1b on Isère river). Results on three Spanish rivers, the Ter, the Llobregat and the Segre, show that 275 floods have been recorded since 1300 up to the present day in the selected cities under study. Girona (Ter) recorded 95 extraordinary and 22 catastrophic floods, Lleida (Segre) 14 and 25, respectively, and the Llobregat mouth 89 and 30 , respectively.
3.2 Historical discharge series based on hydraulic modelling

There are several difficulties in converting historical flood levels $H$ into a flood discharge $Q$. River authorities are responsible for gauging measurements that are used to calibrate the relationship between level and discharge. The quality of this conversion depends on both the hydraulic environment of the gauging station and the water level. The best hydraulic configuration is that produced by a narrow flood section (e.g. gorges or canyons, without a mobile bed-river or a riverbed rock without flood deposits, or ideally an artificial rectangular or $\mathrm{V}$-notch section). This produces a low hydraulic sensitivity $d Q / d H$., i.e. a small variation in flood level $H$ does not lead to a large variation of discharge $Q$. As gauging measurements are usually few for large floods, because of operational constraints (being aware, gaining access, being able to gauge large velocities), the rating curve is generally extrapolated from intermediate floods, such as 1 to 10 year floods.

One way of extrapolating the rating curve is to calibrate a hydraulic model using a knowledge of the topographic survey of the river during the previous centuries and longitudinal profiles of the flood surface water level (SWL). The lack of sufficient data for the Spanish rivers has not allowed such analysis to be conducted. Three case studies have been investigated on French rivers (Lang and Coeur, 2002).

On the Guiers basin, hydraulic modelling has highlighted the poor accuracy of historical discharge estimates when no hydrometric data was available for model calibration (Lang et al., 1998). The present estimate of the 1875 flood discharge at Pont-de-Beauvoisin $\left(480 \mathrm{~km}^{2}\right)$ is between 250 and $285 \mathrm{~m}^{3} / \mathrm{s}$ and differs from the first estimate made in the 19th century of $400 \mathrm{~m}^{3} / \mathrm{s}$, as two different Manning roughness coefficients $n$ were used: $1 / n=25$ today and 35 in the past. From a hydraulic point of view it is difficult to conclude which estimate could be valid, as little information is available on the 1875 flood Surface Water Level (SWL). This uncertainty leads to a range of possible discharge estimates for the same historical level.

On the Isère river, hydraulic modelling showed some lim- 
itation of historical discharge estimates when no detailed information was available on the flood plain topography. The validity of the 1880-1944 rating curve at Grenoble $\left(5700 \mathrm{~km}^{2}\right)$ has been demonstrated by hydraulic modelling for small floods (class 1). Above a discharge threshold of $1000 \mathrm{~m}^{3} / \mathrm{s}$, floods exceed the banks and flow over the whole Grenoble floodplain. As the exact topography of the floodplain (1-2 km wide) is not well known during the 19th century it is still difficult to estimate the flood discharge of extreme historical events.

On the Ardèche river, a detailed hydraulic study with a sensitivity analysis (Lang et al., 2002, 2003) showed that the final error on the largest historical discharge estimate is about $50-80 \%$, which is not very far from what can be expected at good gauging stations (50\% is still a good result). Two case studies have been investigated, just above and below the Ardèche canyon, at Vallon-Pont-d'Arc (Vallon, $1930 \mathrm{~km}^{2}$ ) and St. Martin-d'Ardèche (St. Martin, $2240 \mathrm{~km}^{2}$ ). A 1-D St. Venant hydraulic modelling on the downstream reach of the Ardèche (St. Martin) was carried out. Roughness coefficients have been fitted using the water surface profile from the 1992 flood (5 year flood) and field measurement of discharge. A 1D St. Venant hydraulic modelling study focussed on the Vallon area, based on additional topographic survey, in order to take into account the possible by-passing of the natural arch of Vallon through a secondary branch. The hydraulic model used was able to solve the St. Venant equations with a loop of two branches. After a calibration of the hydraulic model with the present conditions, using detailed information on the 1992 flood, the model has been tested on six historical floods (1827, 1846, 1855, 1857, 1859, 1890) and the 1955 floods, where SWL longitudinal profiles were available. It produced a quadratic difference $\varepsilon$ on water depth of less than $10 \%$ :

$\varepsilon=\frac{100}{N} \sum_{i=1}^{N}\left\{\left[\left(h_{o b s}\right)_{i}-\left(h_{\text {comp }}\right)_{i}\right] /\left(h_{o b s}\right)_{i}\right\}^{2}$,

where $N$ is the number of flood marks, and $\left(h_{o b s}\right)_{i}$ and $\left(h_{\text {comp }}\right)_{i}$ are the observed and computed water depth of mark number $i$.

Then a sensitivity analysis, taking into account the effect of downstream conditions and upstream water levels and variations in riverbed topography provided a rating curve $Q(H)$ with confidence intervals. The final uncertainty on the discharge estimate at St. Martin and Vallon is a function of the date, the water level and the available date and ranged from $10-40,25-40$ and $60-80 \%$ relative errors. Two discharge series are now available at Vallon and St. Martin, providing a continuous series of annual maximum discharges for 1892-2000 and the selection of 15 historical floods from 1644 to 1890 . A range of values has been associated with each discharge estimate, taking into account the uncertainties related to the historical water levels and the rating curves.

\subsection{Bias in historical flood classification}

The first flood event classification is based on flood levels and damage. This could lead to several kinds of bias when deal- ing with natural flood hazards. Flood level is very sensitive to hydraulic works or sediment incision/deposition, which may have changed the relationship between level and discharge. Flood damage is produced by the combination of flood hazard and land-use activities. The increase in flood vulnerability, i.e. urbanisation in the flood prone area, will lead to more frequent damage even if the natural flood hazard remains stable.

Therefore, the historical analysis should provide not only hydrometeorological data, but also information on factors connected with human activities in the territory such as land use, erosion processes, river dynamics and hydraulic works. Whenever possible, the flood event classification should be based on discharge estimates so that each discharge value of the historical data set could then be considered as being produced by the flood regime component, as external human components such as river embankments or a greater exposure to floods, have been filtered out. Some specific problems are related to the availability of old data for model development and calibration, with uncertainties on the expected differences between the past and the present configuration of the river and the catchment.

As the general topographic cover of the main countries in Europe dates from the 18th century, with an altimetric survey from the second half of the 19th century, it is difficult to have an exact knowledge of the river topography over several centuries. A progressive approach allows us to go back in the past:

- A comprehensive chronological account of the successive topographic surveys allows all available cross sections to be easily converted from one reference frame to another. It is then possible to compare the longitudinal profile of the bed river during the last century and to have an understanding of the variations in river morphology.

- Some detailed technical reports from the 19th century give cross sections with only relative altitudes compared to a benchmark and sometimes the SWL of historical floods. A detailed investigation is then necessary to find information which allows conversion of these relative altitudes to modern referenced altitudes using a specific object such as an old monument, house, bridge, dike or road or a characteristic feature of the landscape that is still present and can be surveyed, or a historical account describing the maximum water level with a reference to an existing monument.

- Historical documents up to the 18th century are usually only of qualitative interest. They cannot provide detailed information on the river topography but give general data on the river morphology and the existence of hydraulic structures, road, cities and land use.

A hydraulic model can be developed using the present topography of the river (main channel and flood plain) and hydrometric data for calibration. Then a second hydraulic 

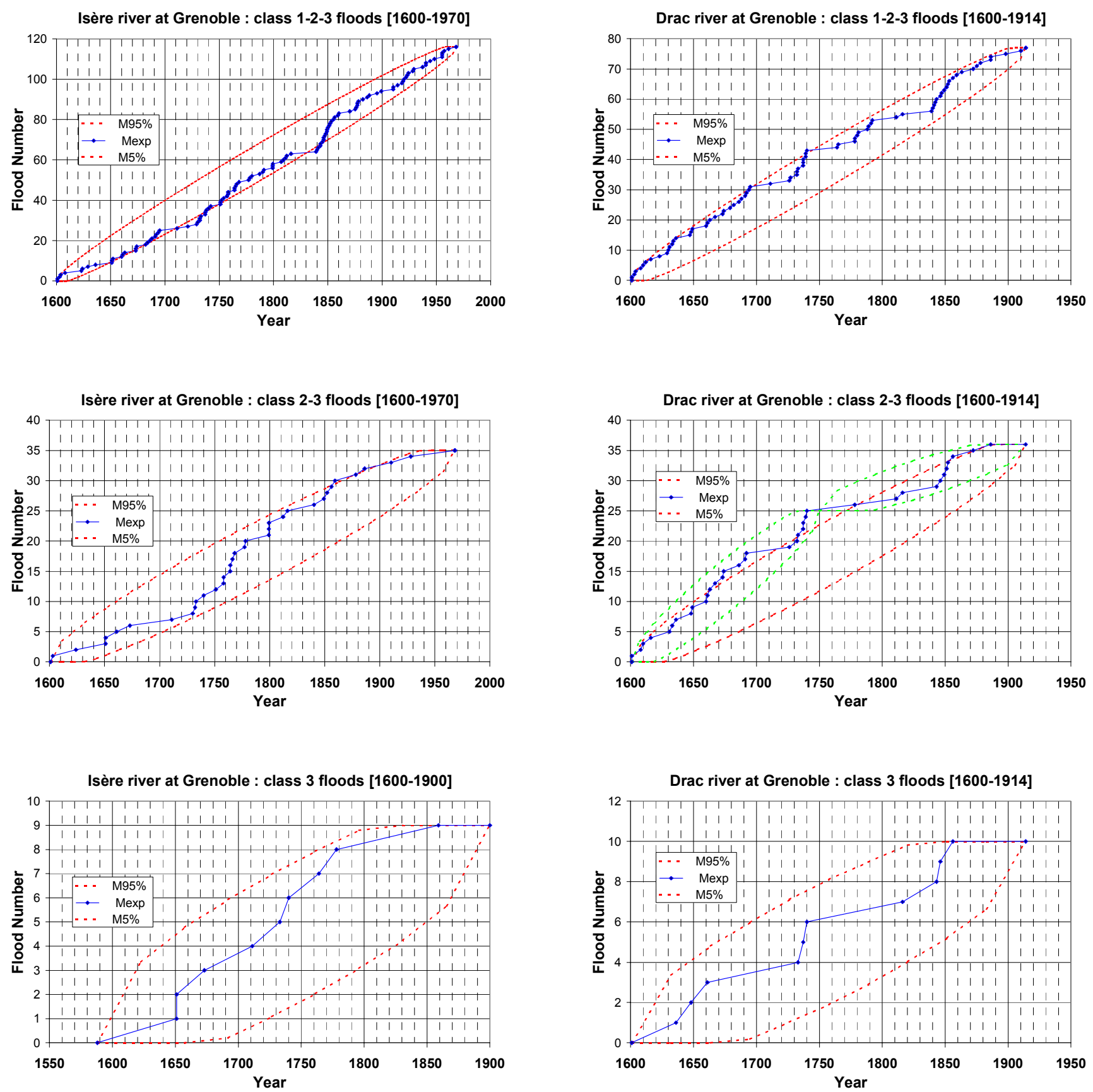

Fig. 2. Poisson test on the time flood process at Grenoble

model can be built, taking into account information on the past river topography. This involves removing recent hydraulic structures from the main channel and changing the bed river altitude or the shape of cross sections whenever necessary. The flood plain topology should also be cleared of those physical components which were not present in the past (motorways, major roads, dikes, railways and modern parts of cities). Finally, whenever possible, the historical flood classification should be based on discharge estimate, with a sensitivity analysis to assess the specific errors of the hydraulic model for the conversion of historical flood levels

$H$ into discharge $Q$. The next section will describe a stationarity analysis of historical series based on the two kinds of classifications.

\section{Homogeneity and quality-control tests}

\subsection{Statistical procedure}

The analysis of past flood events using proxy data can be of benefit to the understanding of large flood processes. It enlarges the flood chronology and increases the number of 


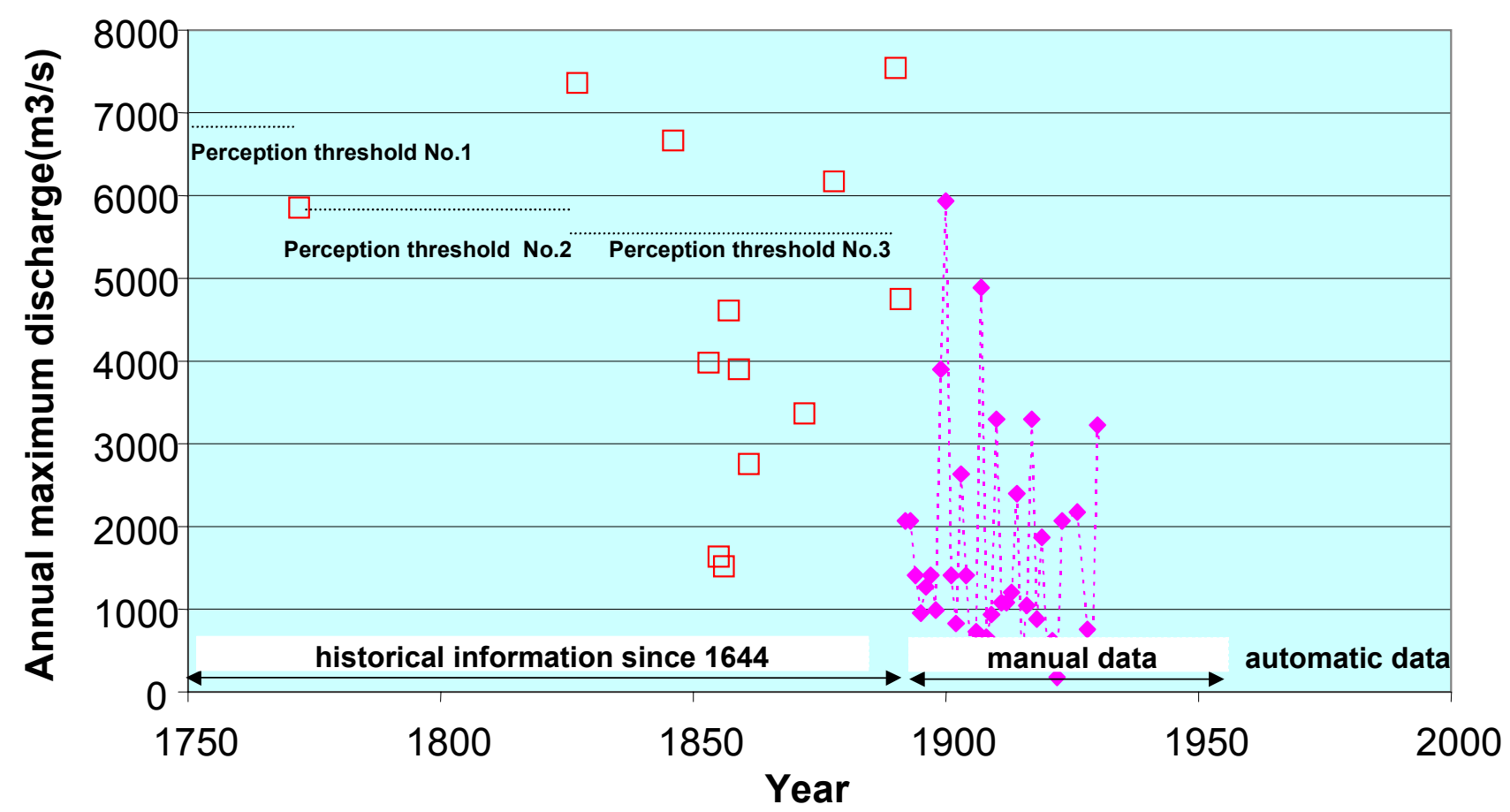

Fig. 3a. Historical flood discharge series (1644-2000) at St. Martin on Ardèche river.
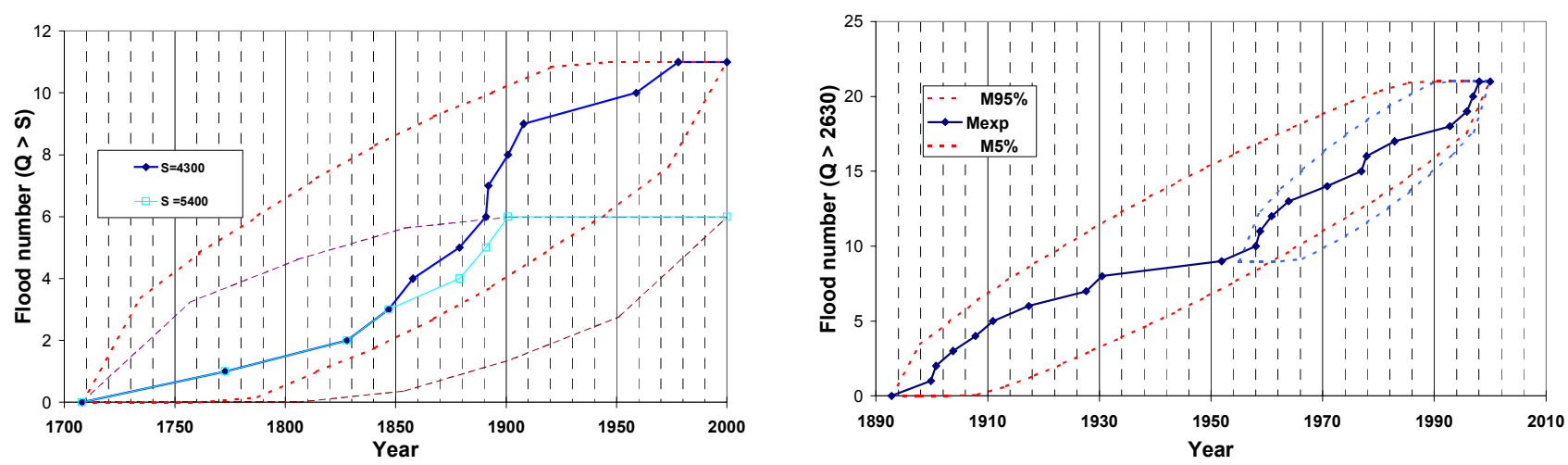

Fig. 3b. Poisson test on the time flood process at St. Martin on Ardèche river.

observations of extreme events. But it is necessary to use scientific tools to identify homogeneity problems caused by the quality of documentary sources, by human activities close to riverbeds and natural climatic variability patterns. A large set of statistical tests is available when detecting a trend or other changes in hydrological data (WMO, 2000).

After an exploratory/visual analysis which involves graphical tests on several topics such as temporal patterns, seasonal variations, regional and spatial patterns, data problems and correlations, statistical tests provide tools to help decide which hypothesis can be considered as the most realistic. The procedure is generally divided into the following steps: 1) defining the null $H_{0}$ and the alternative $H_{1}$ hypotheses, such as no trend in the mean of a series versus a trend; 2) defining a test statistic $T$ which provides a numerical value $t$ for the comparison of the two hypotheses on the data sample; 3) defining a significance level $\omega$ which will be related to the probability that the test detects a trend when none is present; 4) comparing the probability of exceedance $p=\operatorname{Prob}[T>t]$ with the significance level $\omega$, and deciding if the hypothesis $H_{0}$ can be accepted. The general decision criteria is usually the following: if $p>0.10$, there is very little evidence against the null $H_{0}$ hypothesis; if $p$ is between 0.05 and 0.10 this provides possible evidence against $H_{0}$; if $p$ is between 0.01 and 0.05 there is strong evidence against $H_{0}$ and if $p<0.01$ there is very strong evidence against $H_{0}$.

The vast majority of statistical tests on extreme values deal with annual maximum or minimum series. These kinds of tests cannot be used with historical series, where the requirement of continuity within the data records is not fulfilled year by year. A good alternative is to use peak over threshold series, which contain the entire event larger than a threshold. 

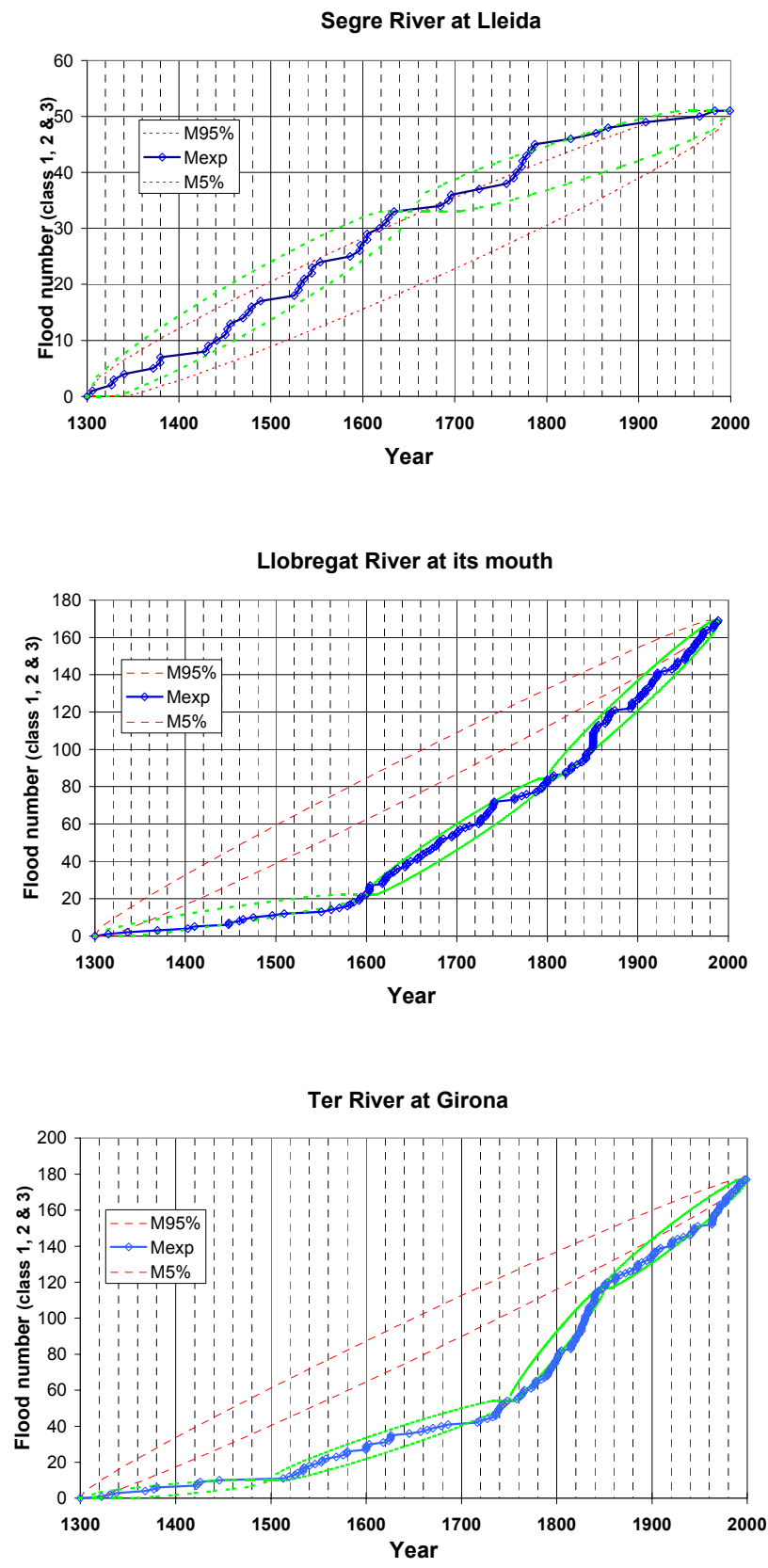

Fig. 4. Poisson test on the time flood process in Spanish rivers: class 1-2-3 events.

Lang et al. (1999) provided some guidelines for choosing an appropriate threshold. This includes a stationarity test based on the computation of the tolerance interval of the number $m_{t}$ of floods within an interval $[0 ; t]$. The null hypothesis $H_{0}$ is to assume that the flood process can be described by a homogeneous Poisson process, such as:

$\operatorname{Prob}\left[m_{t}=k\right]=\exp (-\mu t)(-\mu t)^{k} / k$ !

The test has been applied to historical data series, using different thresholds related either to a class ranking or to a discharge value. A rejection of the test (Fig. 2), which is characterised by the output of the cumulative number of floods (central continuous curve with marks) outside the $90 \%$ tolerance interval (95\% and 5\% quantiles with dotted lines), implies the non-compliance with the Poisson process hypotheses (i.e. non-independent and non-homogeneous values). This could be caused either by a non-exhaustive historical account of flood events (Sect. 2.2), or by a bias in the perception of the flood chronology (Sect. 3.3), or by climate variability in the flood process.

\subsection{Homogeneity test on French data}

It is difficult to produce hydrological conclusions on data before 1600. A few floods have been found, but the main explanation could be a non-exhaustiveness of flood archives. From 1600 to the present today, the analysis on the Drac and Isère data series is as follows. Small floods do not exhibit specific non-homogeneous behaviour, except for some clustering (Fig. 2, class 1-2-3). Historical analysis does not provide an exhaustive inventory of small floods. It is better to examine intermediate and large floods (classes 2 and 3) which are not distributed uniformly with time (Fig. 2, class 2-3). It is evident that there were more floods in the 18th century, especially between 1740 and 1760 . The largest floods are uniformly distributed in time within the period 1600-1900 (Fig. 2, class 3). No major flood occurred during the 20th century.

From 1700 to the present day, the analysis on the Ardèche at St. Martin is as follows. We consider three different periods (Fig. 3a), taking into account the type of available data: gauging station (1955-2000), water level scale (1892-1954) and historical data (1708-1891). We associate a discharge with each flood event by hydraulic modelling and to each period a threshold $S$ of exhaustiveness, i.e. we can consider that no flood event larger than $S$ is missing. The hypothesis of a fit to a Poisson process can be accepted for each of the three periods (Fig. 3b). A lower threshold must be adopted for the 1700-2000 period in order to have additional floods during the 20th century ( $S=4300$ instead of $5400 \mathrm{~m}^{3} / \mathrm{s}$ ).

\subsection{Homogeneity test on Spanish data}

The complete small floods data set shows a bias in temporal occurrence (Fig. 4), as two of the three rivers (except the Segre) have an increasing number of events with time. This is felt to be a problem of non-exhaustiveness in the records of level 1 flood events. The same behaviour is found with intermediate and large floods (classes 2 and 3). From 1300 to the present day, non-uniform behaviour is observed, with more floods in the period 1300-1650 than 1650-2000 for the River Segre, but the other way round for the River Llobregat, and an increasing number of events with time for the River Ter. The largest floods are homogeneously distributed in time within the period 1300-1900, for the Segre and Ter rivers (Fig. 5). The River Llobregat has a complex time process, with two active periods, $1580-1700$ and 1840-1870, and two periods without large floods: $1315-1580$ and 1700 1840 (Fig. 5). 
Segre River at Lleida

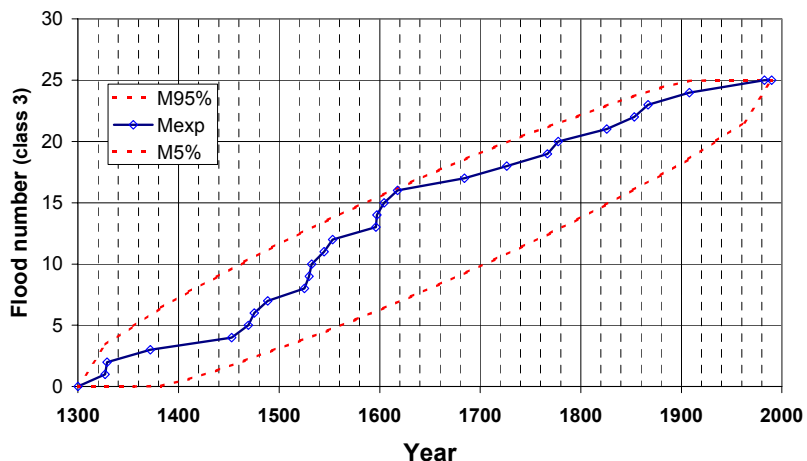

Llobregat River at its mouth

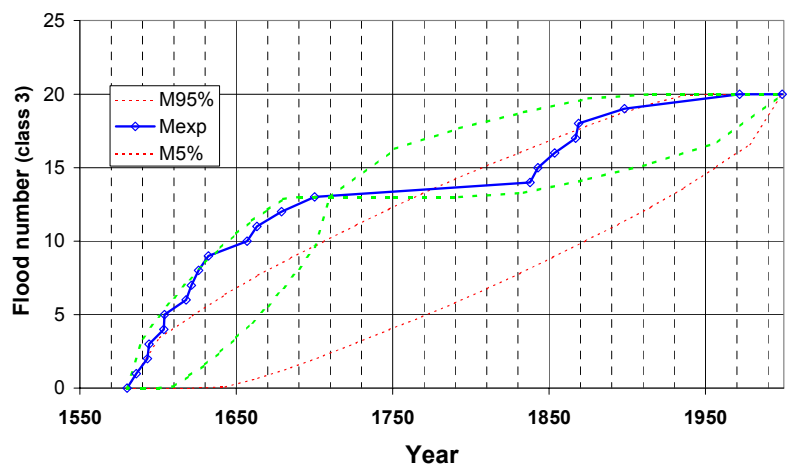

Ter River at Girona

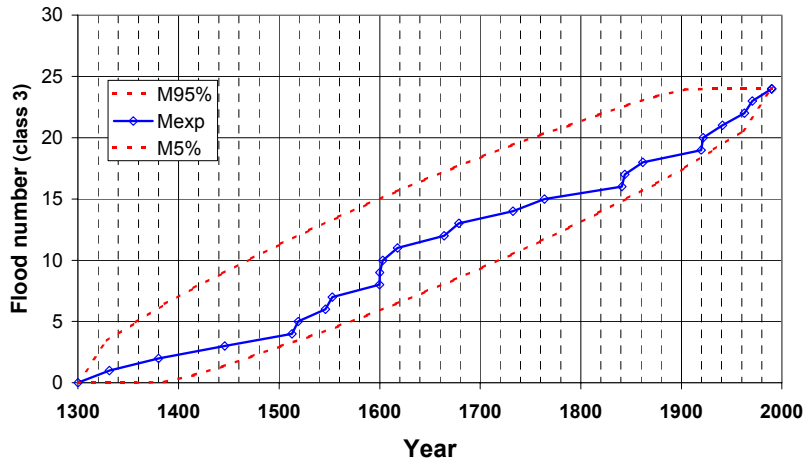

Fig. 5. Poisson test on the time flood process in Spanish rivers: class 3 events.

\subsection{Conclusion on historical data homogeneity}

Historical analysis provides an opportunity to enlarge the time scale window for flood risk analysis. The present work indicates that a high threshold should be used, in order to select an exhaustive sample of events. When this requirement is not fulfilled, historical analysis is too dependent on archive availability or flood risk exposure, which means that there is no clear relationship between the existence of events within archives and the real flood time series. The present historical investigation on Spanish and French rivers recorded on av- erage twenty to thirty flood events per century. This amount should be reduced to the largest three or four events per century, in order to produce an exhaustive and homogeneous sample.

When dealing only with the largest floods, the statistical tests show a good stationarity of the flood occurrence process. Historical analysis is then able to provide some useful information for flood hazard assessment. When historical data is not only considered within a class of damage but as a discharge value, the statistical use is easier (e.g homogeneity), and can be extended to extraordinary floods, if the exhaustiveness of the sample is verified. The example of the historical series of the Ardèche river shows that it is possible on average to retain the twenty largest floods per century, when historical flood levels have been converted into discharge.

\section{Concluding remarks}

Historical documentary sources have a good potential for reconstructing exceptional flood events during the past 1000 years throughout Europe. Usually, the quality of sources allows the generation of continuous data series. Subsequently, palaeoclimatic research at least for frequencial analysis must be carried out. Information on hydrological data is not easy to manage and requires the use of historiographical techniques and also detailed work with complementary sources (old maps, drawings, public works files).

The comparison between the French and Spanish analysis shows that flood classifications helps in the objectivization and quantification of information for generating data series. Finally, these data series and their values are highly suitable for use in comparative analysis. Only if historical flood chronologies reach this level of classification can coherent hydrological/hydraulic and climatic/meteorological analysis be deployed. It is a parsimonious method of quantification but it allows the introduction of a minimum amount of consistently available information for other data series collected in future research.

The conversion of historical information concerning water levels into quantitative values of water discharges is a delicate process in which a large amount of complementary information must be collected and analysed: different riverbed configurations, human factors (infrastructure, activities), land uses and their changes throughout historical time. It provides a long series with more representative values of the physical phenomena than with the damage index alone.

Statistical tests provide criteria to objectively select the best flood series from historical sources. After this step, the hydrological analysis of historical data is more realistic and calibration with instrumental series can be made. This step of detailed analysis in an interdisciplinary framework is a good basis for future research on reconstructing extreme environmental events.

Future research work could include the introduction of meteorological and climatic analysis. Like hydrological studies, 
meteorology can improve the research on the weather patterns that produce heavy rainfall and floods. Reconstructing extreme events and their impacts from documentary sources offers a qualitative overview, not in all cases useful for environmental research. But, despite the limited amount of information for the past millennium, old meteorological records at a daily resolution have interesting potentials. For the past 250 years, modest but systematic synoptic reconstructions can be made, including heavy rainfall events. This information is a tool for helping to characterise different extreme meteorological events, such as heavy rainfalls, that occur at such low frequencies that it has been difficult to detect them during the modern instrumental period. This potential analysis has an important applied component, as a useful tool for aid in risk planning, forecasting and other land-use management strategies.

Acknowledgements. This research was developed in the framework of the European SPHERE project (EVG1-CT-1999-00010).

\section{References}

Alexandre, P.: Le climat en Europe au Moyen Age. Contribution à l'histoire des variations climatiques de 1000 à 1425 d'après les sources narratives de l'Europe occidentale, Ecole des Hautes Etudes en Sciences Sociales, Paris, 1987.

Barriendos, M. and Pomés, J.: L'aigua a Mataró. Inundacions i recursos hidrics (Segles XVIII-XX), Mataró, "Caixa d'Estalvis Laietana", 278, 1993.

Barriendos, M., Llasat, M. C., and Rodriguez, R.: Frequency of Heavy Rains and Floods in Northeast Spain since the 15th Century, Proceedings of the 2nd International Conference on Climate and Water, Espoo, Finland, 1, 391-399. 1998.

Barriendos, M. and Martin-Vide, J.: Secular Climatic Oscillations as Indicated by Catastrophic Floods in the Spanish Mediterranean Coastal Area (14th-19th Centuries), Climatic Change, Kluwer Academic Publishers, 38, 473-491, 1998.

Benito, G., Lang, M., Barriendos, M., Llasat, M. C., Francés, F., Ouarda, T., Thorndycraft, V., Enzel, Y., Bardossy, A., Coeur, D., and Bobée, B.: Use of Systematic, Palaeoflood and Historical data for the improvement of flood risk estimation, Review of scientific methods - Natural Hazards; special issue from the EGS 2000 Congres, NH4.03 session "The use of historical data in natural hazard assessment : Floods", Nice, France, 25-29 April. In press.

Brázdil, R., Glaser, R., Pfister, C., Antoine, J. M., Barriendos, M., Camuffo, D., Deutsch, M., Enzi, S., Guidoboni, E., Rodrigo F. S.: Flood events of selected rivers of Europe in the Sixteenth Century, Climatic Change, 43, 239-285, 1999.

Coeur, D., Lang, M., Naulet, R., Burnet, R., and Strazzeri, D.: Histoire et connaissance des phénomènes naturels extrêmes Ingénieries EAT - numéro spécial Risques Naturels, 15-26, 1998.

Coeur, D. and Lang, M.:L'enquête en archives et la connais- sance des inondations, in Avalanches et risques. Regards croisés d'ingénieurs et d'historiens, Actes du séminaire du programme Histoval (Grenoble, 16 September 1999), Cemagref-Université Pierre Mendès France (CRHIPA/HESOP), Grenoble, MSHAlpes, 133-144, 2002.

Glaser, R. and Stangl, H.: Floods in Central Europe since 1300, edited by Thorndycraft, V. R., Benito, G., Llasat, M. C., and Barriendos, M., Palaeofloods, historical data and climatic variability: applications in flood risk assessment, Proc. of the PHEFRA Workshop, Barcelona, Spain, October 2002, 93-98, 2003.

IPCC: Climate Change 2001, Impacts, Adaptation and Vulnerability, Cambridge University Press, 2001.

Lang M. and Coeur D.: Flood knowledge: history, hydraulics and hydrology. Case study on three French rivers, AFCRST Paris, Colloque Franco-Chinois sur la protection et l'utilisation durable de la ressource en eau, Chinese-French Conference on water resources, Shanghai/Suzhou, 6-9 November, 96-102, 2002.

Lang, M., Coeur, D., Lallement, C., and Naulet, R.: Valorisation de l'information historique pour la prédétermination du risque d'inondation: application sur le bassin du Guiers, Ingénieries EAT, no. 16, December, 3-13, 1998.

Lang, M., Ouarda, T., and Bobée, B.: Towards operational guidelines for over-threshold modeling, J. of Hydrol., 225, 103-117. 1999.

Lang, M., Naulet, R., Recking, A., Coeur, D., and Gigon, C.: Etude de cas: l'analyse des pluies et crues extrêmes observées depuis 200 ans dans un bassin cévennol, l'Ardèche, La Houille Blanche, no. 6/7, 131-138. 2002.

Lang, M., Moussay, D., Recking,, A., and Naulet, R.: Hydraulic modelling of historical floods, Case study on the Ardeche river at Vallon-Pont-d'Arc, Palaeofloods, historical data and climatic variability: applications in flood risk assessment, edited by Thorndycraft, V. R., Benito, G., Llasat, M. C., and Barriendos, M., Proc. of the PHEFRA Workshop, Barcelona, Spain, October 2002, 183-190, 2003.

Le Roy Ladurie, E.: Histoire du climat depuis l'an mil, Flammarion, Paris. 1967.

Llasat, M. C. and Barriendos, M.: Availability and potential of historical flood series in the Iberian Peninsula (14th-20th centuries), The Use of Historical Data in Natural Hazard Assessments, Dordrecht/Boston/London, Kluwer Academic Publishers, 131-140, 2001.

Naulet, R., Lang, M., Coeur, D., and Gigon, C.: Collaboration between historians and hydrologists on the Ardeche river (France), First step: Inventory of Historical Flood Information, in The Use of Historical Data in Natural Hazard Assessments, edited by Glade, T., Albini, P., and Francès, F., Dordrecht/Boston/London, Kluwer Academic Publishers, 113-129, 2001.

Pfister, C.:Klimageschichte der Schweiz 1525-1860, Das Klima der Schweiz von 1525-1860 und seine Bedeutung in der Geschichte von Bevölkerung und Landwirtschaft, Academica Helvetica 6, Verlag Paul Haupt, Bern, 1988.

WMO: Detecting a trend or other changes in hydrological data, WCDMP 45, CEH Wallingford, WMO/TD 1013, edited by Kundzewicz, Z. and Robson, A., Geneva, May, 158, 2000. 